\title{
Van Koşullarında Yetiştirilen Silajlık Mısır (Zea mays L.) ve Ayçiçeği (Helianthus annuus L.)'nin Verim Parametreleri ve Besin Madde Kompozisyonuna Ait Kalite Özellikleri*
}

\author{
Serhat YILDIZ ${ }^{1}$, Sibel ERDOĞAN ${ }^{2 * *}$ \\ ${ }^{1}$ Van Yüzüncü Yıl Üniversitesi, Gevaş Meslek Yüksekokulu, Laboratuvar ve Veteriner Sağlık Programı, Gevaş-Van, TÜRKIYYE \\ ${ }^{2}$ Van Yüzüncü Yıl Üniversitesi, Ziraat Fakültesi, Zootekni Bölümü, Van, TÜRKIYYE
}

\begin{tabular}{ll}
\hline \multicolumn{1}{c}{ Geliş Tarihi/Received: 06.09 .2018} & Kabul Tarihi/Accepted: 16.10 .2018 \\
\hline ORCID ID (Yazar strastna göre / by author order) \\
\hline (D) orcid.org/0000-0003-1063-4704 (D) orcid.org/0000-0003-2640-3871 \\
${ }^{* *}$ Sorumlu Yazar/Corresponding Author: serdogan@yyu.edu.tr
\end{tabular}

Öz: Bu çalışma, Van ili Gevaş ilçesi sulu koşullarında yetiştirilen silajlık mısır (Zea mays L.) ve ayçiçeği (Helianthus annuus L.)'nin bazı verim parametreleri ile besin madde komposizyonuna ait kalite özelliklerini belirlemek amaciyla yürütülmüștür Araştırmada; OSSK 644 mısır ve KAAN ayçiçeği çeşidi kullanılmış olup, tarla denemesi tesadüf blokları deneme desenine göre 3 tekrarlamalı olarak kurulmuştur. Mısır ve ayçiçeği bitkilerinin ekimleri, $70 \mathrm{~cm}$ sıra aralı̆̆ 1 ve $25 \mathrm{~cm}$ sıra üzeri olacak şekilde yapılmıştır. Yeşil ot ve kuru madde verimi bakımından silajlık mısır $\left(6586.55 \mathrm{~kg} \mathrm{da}^{-1}, 1796.21 \mathrm{~kg} \mathrm{da}^{-1}\right)$ ve ayçiçeği $\left(6404.76 \mathrm{~kg} \mathrm{da}^{-1}, 1517.23 \mathrm{~kg} \mathrm{da}^{-1}\right)$ arasında farklılık bulunmazken, bitki boyu ve koçan/tabla oranı bakımından ise istatistik olarak çok önemli $(\mathrm{p}<0.01)$ farklılık saptanmıştır. Çalışmada, ayçiçeği silajında HK, HP, HY ve ADF içerikleri sırasıyla \% $11.02, \% 11.19, \% 14.63$ ve \% 39.74 olarak belirlenmiş olup, bu besin maddelerine ait kalite özellikleri bakımından mısır silajı için elde edilen değerlerden (HK \% 5.15, HP \% 4.80, HY \% 6.69 ve ADF \% 30.47) daha yüksek olduğu gözlenmiștir ( $\mathrm{p}<0.05$ ). Araştırma sonucunda; Van ekolojik koşullarında mısır silajına alternatif olarak ayçiçeğinin silajlık olarak yetiştirilebileceği sonucuna varılmıştır.

Anahtar Kelimeler: Ayçiçeği, mısır, silaj, verim, kalite özellikleri

\section{Quality Traits of the Nutrient Matter Compositions and Yield Parameters of Planted Silage Corn (Zea mays L.) and Sunflower (Helianthus annuus L.) at Conditions of Van}

\begin{abstract}
This study was carried out to determine the quality characteristics of the nutrient composition with some yield parameters of silage corn (Zea mays L.) and sunflower (Helianthus annuus L.) grown in the irrigated conditions of Gevaş province of Van. In the study; OSSK 644 corn and KAAN sunflower varieties were used and field trial was established with randomized complete blocks design with 3 replications. The corn and sunflower seeds were planted $70 \mathrm{~cm}$ x $25 \mathrm{~cm}$ at row arrangements. There was no significant difference between the corn $\left(6586.55 \mathrm{~kg} \mathrm{da}^{-1}, 1796.21 \mathrm{~kg} \mathrm{da}^{-1}\right)$ and the sunflower $\left(6404.76 \mathrm{~kg} \mathrm{da}^{-1}, 1517.23 \mathrm{~kg} \mathrm{da}^{-1}\right)$ in terms of the yield of forage and dry matter, while the difference between plant height and cob / table ratio of its was significant $(\mathrm{p}<0.01)$. Values of $\mathrm{CA}, \mathrm{CP}, \mathrm{CF}$ and $\mathrm{ADF}$ for sunflower silage was found to be $11.02 \%, 11.19 \%, 14.63 \%$ and $39.74 \%$, respectively and was higher than corn silage values $(5.15 \%, 4.80,6.69 \%$ and $30.47 \%$, respectively) $(\mathrm{p}<0.05)$. In conclusion, sunflower can be advised as an alternative to corn as silage in the Van ecological conditions.
\end{abstract}

Keywords: Sunflower, corn, silage, yield, quality properties

\footnotetext{
": Bu çalışma, Van Yüzüncü Yıl Üniversitesi Fen Bilimleri Enstitüsü’nde yürütülen birinci yazara ait Doktora Tez çalışmasının bir bölümünden üretilmiştir.
} 


\section{Giriş}

Doğu Anadolu Bölgesi'nde uzun süren kış aylarında hayvanların barınaklarda beslenme zorunluluğu vardır. Ancak bölgede hayvanların kaliteli kaba yem ihtiyaçları tam olarak karşılanamamaktadır. Tarım arazilerindeki yem bitkileri ve çayırlardan üretilen ot, kış beslemesi için yeterli gelmemekte, bu yüzden yem değeri çok düşük olan tarla bitkileri artıkları yem olarak kullanılmaktadır. Nitekim 2012 yılında yaşanan kuraklık nedeniyle kaba yem üretimi düşmüş, başta Doğu Anadolu olmak üzere Türkiye'nin birçok yerinde büyük çaplı kaba yem açığı ortaya çıkmıştır. Ekonomik ve karlı bir hayvansal üretim yapabilmek için öncelikli hedef ucuz, kaliteli kuru ve sulu kaba yem teminidir.

Kuru madde (KM) içeriğinin oransal olarak yüksek olması, tampon kapasitesinin düşük olması ve laktik asit fermantasyonu için gerekli olan suda eriyebilir karbonhidratları yeterli düzeyde bulundurması nedeniyle en fazla tercih edilen silajlık yem bitkisi mısırdır. Ancak Doğu Anadolu Bölgesi'nde; Van, Erzurum, Ağrı, Kars ve Ardahan platosu yüksek rakım, düşük sıcaklıklar ve kısa gelişme periyodu nedeniyle, bir sicak mevsim bitkisi olan mısır tarımına çok uygun değildir. Doğu Anadolu'nun bu yöresinde mısır tarımı için gerekli olan en az 90 günlük don olmayan güvenli periyodu yakalamak zordur (Serin ve Tan, 1998). Doğu Anadolu Bölgesi'nde ilkbaharın son donları Mayıs ayına sarkabilmekte, sonbaharın ilk donları da Eylül ayı başlarında gerçekleşebilmektedir. Bu durum silajın yaygınlaştırılması için bölgede yapılan çalışmalarda önemli bir sorun oluşturmakta, üreticilerin silajlık mısır yetiştiriciliğine temkinli yaklaşmasına yol açmaktadır (Serin ve Tan, 1998). Silaj üretiminde mısırdan vazgeçmek mümkün değilse de, son yıllarda alternatif silaj bitkileri konusunda çalışmalar yapılmaktadır.

Ayçiçeği (Helianthus annuus L.) Doğu Anadolu Bölgesi'nin en k1sa vejetasyon süresine sahip yerlerinde dahi çerezlik amacıyla yetiştirilmektedir. Mısıra göre tarımı daha kolaydır. Bu özelliğe sahip yerlerde kısa sürede silajlık biçime gelen, sıcağa ve soğuğa toleransı oldukça yüksek ve dahası farklı toprak şartlarına karşı adaptasyon yeteneği fazla olan ayçiçeğinden kaliteli bir yem bitkisi olarak yararlanılabilmektedir.

Misır tarımında uygun büyüme sıcaklığı 24-32 ${ }^{\circ} \mathrm{C}$ olup, gelişme dönemi boyunca toplam sıcaklık isteği bölge ve çeşitlere göre $2000-4000^{\circ} \mathrm{C}$ arasında değişir (Kırtok, 1998). Nemin \% 60’ın altına düşmemesi istenir. Buna karşılık ayçiçeği, vejetasyon periyodu (80-130 gün) süresince toplam sicaklık ihtiyacı 2600-2850 ${ }^{\circ} \mathrm{C}$ 'dir. Çimlenme süresinde en düşük olarak $4-5^{\circ} \mathrm{C}$, uygun bir çıkış için ise en azından $8-10{ }^{\circ} \mathrm{C}$ ve optimum olarak 12 $14{ }^{\circ} \mathrm{C}$ sicaklık gereklidir. Gelişme döneminde 30 ${ }^{\circ} \mathrm{C}$ 'nin üzerindeki sıcaklık dereceleri büyümeyi engellemektedir (Serin ve Tan, 1998). Ayçiçeği, derinliği yaklaşı1 $2 \mathrm{~m}$ olan toprakta var olan suyun \% 92'sini kullanma yeteneğine sahiptir (Evangalista ve Lima, 2001). Böylece hayvan beslemede ayçiçeği silajının kullanımı özellikle susuzluk durumlarında alternatif bir silajlık yem bitkisi olarak değerlendirilebilir.

Van ve çevre iller hayvancılığın çok yoğun olarak yapıldığı yerlerdir. Kış aylarında kaliteli kaba yem açığının ortaya çıktığı bu yörede, silaj tekniği ve mısıra alternatif olarak ayçiçeği tarımının geliştirilmesine ihtiyaç vardır. Bunun için de yöreye uygun, hem verimli hem de silajlık değeri yüksek olan ayçiçeğinin silajlık veriminin belirlenmesi gerekir. Bu araştırma, Van ve benzeri bölgeler için silajlık mısır ve ayçiçeğinin verim ve besin maddelerine ait kalite özelliklerinin belirlenmesi amacıyla planlanmıştır.

\section{Materyal ve Yöntem}

Araştırmada bitkisel materyal olarak; TAREKS Tohumculuk'tan temin edilen ve tek melez şeklinde 1slah edilen OSSK 644 silajlık mısır çeşidi ile Trakya Tarımsal Araştırma Enstitüsü ve Alfa Tohumculuk'tan temin edilen KAAN ayçiçeği tohumu kullanılmıştır.

Mısır ve ayçiçeği ekimi; Van ili Gevaş ilçesinde sulu bir arazide, $70 \mathrm{~cm}$ sira aralığı ve $25 \mathrm{~cm}$ sira üzeri olacak şekilde olacak şekilde pnömatik mibzer ile 2014 Mayıs ayında yapılmıştır. Ekim sırasında, dekara $9 \mathrm{~kg}$ üre [\% 45-46 N (azot)]ve 15 $\mathrm{kg}$ triple süper fosfat [\% 43-46 P (fosfor)] gübresi uygulanmıştır. Bitkiler 30-40 cm boylanınca ara çapasından önce boğaz doldurma ile birlikte tekrar dekara $9 \mathrm{~kg}$ üre gübrelemesi yapılmıştır (İptaş ve ark., 1997).

Silajlık bitkiler, yağmurlama ve salma sulama yöntemlerinden faydalanılarak sulanmıştır. Çıkış ve erken gelişme döneminde bitkilere 30-40 cm'ye ulaşıncaya kadar yağmurlama sulama, çiçeklenme öncesi ve sonrası dönemlerde ise yağış ve bitkilerin morfolojik görünüşü dikkate alınarak ortalama 15 günde bir (bitki 1 m'ye ulaştığında) salma sulama yapılmıştır. Yabancı ot mücadelesi için bitki çıkışlarından sonra (bitki 5-6 yaprak olduğunda) birinci el çapas1, bitkiler 30-40 $\mathrm{cm}$ boylandıtan sonra ise ikinci el çapası yapılmıştır.

Mısır ve ayçiçeği bitkilerinin hamur olum döneminin başında, daneler sertleşmeden, incelenmesi gereken verime ait bazı özellikler için, 5 m'lik alanda üç tekerrürlü olarak bir sıra kenar tesiri atıldıktan sonra orakla biçim yapılmıştır. 
Biçilen bitkilerde, Yılmaz ve Hoşaflıoğlu (1999) tarafından bildirilen esaslar dâhilinde aşağıda belirtilen ölçüm ve tartımlar yapılmıştır.

Bitki boyu (cm): Her bir parselden tesadüfi olarak seçilen 10 bitki esas alınmak suretiyle; ayçiçeğinde bitkinin kök kısmından çiçek tablasının altına kadar olan kısmı ölçülerek, mısırda ise toprak yüzeyi ile bitkinin tepe püskülünün ilk yan dalcığının çıktığı boğum arasındaki uzunluk ölçülerek, cm cinsinden ortalama bitki boyları belirlenmiştir.

Yaprak, sap, tabla ve koçan oranlarl (\%): Her bir parselden tesadüfi olarak seçilen 10 bitkinin; yaprak, sap ve tabla kısımları ayrı ayrı tartılarak toplam bitki ağırlığına oranlanmak suretiyle $\%$ oranları belirlenmiştir.

Yeşil ot verimi $\left(\mathrm{kg} \mathrm{da}^{-1}\right)$ : Hasat döneminde her bir parselin kenarlarından birer sıra kenar tesiri olarak atıldıktan sonra, kalan bitkiler hasat edilmiş ve tartılmış, parsel alanı dikkate alınarak dekara yeşil ot verimi bulunmuştur.

Kuru madde (KM) verimi $\left(\mathrm{kg} \mathrm{da}^{-1}\right)$ : Biçilen 10 bitki örnekleri önce laboratuvar ortamında bir süre soldurulmuş, daha sonra $65{ }^{\circ} \mathrm{C}^{\prime}$ ye ayarlı kurutma dolabında 48 saat süre ile kurutularak kuru madde oranları belirlenmiştir. Belirlenen KM oranları ile yeşil ot verimleri çarpılarak dekara KM verimleri hesaplanmıştır.

Hamur olum döneminde silotrakla hasat edilen mısır ve ayçiçeği hasılları, Van Yüzüncü Yıl Üniversitesi Araştırma ve Uygulama Çiftliği Müdürlüğü'ne ait beton silolarda traktör ile sıkıştırılarak hava almayacak şekilde 90 gün fermantasyona bırakılmıştır. Fermantasyon sonunda açılan silajlarda; KM, ham kül (HK), ham protein (HP) ve ham yağ (HY) analizleri Weende analiz yöntemine göre (Anonymous, 1990), asit deterjanda çözünmeyen lif (ADF) ve nötral deterjanda çözünmeyen lif (NDF) oranı analizleri Van Soest ve Robertson (1979) tarafindan bildirilen yönteme göre yapılmıştır.

Araştırma sonucunda elde edilen veriler, tesadüf blokları deneme desenine göre tek yönlü ANOVA varyans analizine tabi tutulmuştur (Anonymous, 2017). Ortalamalar arasındaki farklılik $\mathrm{p} \leq 0.05$ önem seviyesine göre DUNCAN çoklu karşılaştırma testiyle belirlenmiştir.

\section{Bulgular ve Tartışma}

Araştırmada kullanılan misır ve ayçiçeği hasıllarının verim parametrelerine ilişkin en küçük kareler ortalaması ve standart hata sonuçları Tablo 1 'de verilmiştir.

Hayvansal üretime yem sağlama adına yapılan bitkisel üretimde en önemli amaçlardan birisi yüksek verim elde etmektir. Çalışmanın yürütüldüğü Van ili Gevaş ilçesi koşullarında silajlık mısır ve ayçiçeği bitkilerinin, yeşil ot veriminin sirasiyla $6586.55 \mathrm{~kg} \mathrm{da}^{-1}$ ve $6404.76 \mathrm{~kg}$ $\mathrm{da}^{-1}$ ve kuru madde verimlerinin ise sirasiyla

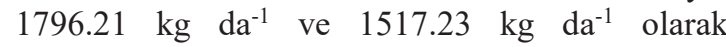
belirlenmiştir. Mısır ve ayçiçeği hasıllarından elde edilen verim değerleri arasındaki farklılıklar istatistiksel olarak önemsiz bulunmuştur. Yem bitkilerinde yemin kalitesini ve lezzetliliğini önemli derecede etkileyen unsurlardan biri olan yaprak oranı bakımından, mısır ve ayçiçeği arasındaki farklılık istatistiki olarak önemsiz bulunmuştur. Ancak hâsıl verimini direkt olarak etkileyen bitki boyu bakımından ise ayçiçeği $(2.00 \mathrm{~m})$ ile karşılaştırıldığında, OSSK 644 hibrit mısır çeşidinin $(3.50 \mathrm{~m})$ daha uzun boylu ve ince saplı olduğu görülmüştür $(\mathrm{p}<0.01)$ (Tablo 1).

Türkiye'nin değişik ekolojik koşullarında mısır ve ayçiçeği çeşitlerinin silajlık verimlerini tespit etmek amacıyla bir çok çalışma yürütülmüştür. Güney ve ark. (2010), 2005 ve 2006 yıllarında Erzurum şartlarında bazı silajlık mısır çeşitlerinin verim ve silaj kalitelerinin belirlenmesi amacıyla yaptıkları çalışmada, ortalama yeşil ot ve KM verimlerini sırasıyla $6233 \mathrm{~kg} \mathrm{da}^{-1}$ ve $1664.83 \mathrm{~kg}$ $\mathrm{da}^{-1}$ olarak belirlemişlerdir. Yapılan başka bir çalışmada, Antalya koşullarında ikinci ürün olarak yetiştirilen OSSK 644 silajlık mısır varyetesinde; yeşil ot ve kuru madde verimi, koçan oranı ve bitki boyu değerleri sirasıyla $5534 \mathrm{~kg} \mathrm{da}^{-1}$ ve $1877 \mathrm{~kg}$ $\mathrm{da}^{-1}, \% 38.3$ ve $275 \mathrm{~cm}$ olarak bulunmuştur

Tablo 1. Mısır ve ayçiçeği hasıllarının verim ve bazı verim öğelerine ilişkin en küçük kareler ortalaması ve standart hata sonuçları ${ }^{1}$

\begin{tabular}{llccc}
\hline Tarımsal özelikler & $\mathrm{n}$ & Misır hasılı & Ayçiçeği hasılı & P değeri \\
\hline Yeşil ot verimi, kg da ${ }^{-1}$ & 3 & $6586.55 \pm 280.32$ & $6404.76 \pm 562.6$ & 0.7868 \\
Kuru madde verimi, kg da ${ }^{-1}$ & 3 & $1796.21 \pm 181.28$ & $1517.23 \pm 131.55$ & 0.2809 \\
Yaprak oranı, \% & 3 & $17.80 \pm 0.85$ & $16.23 \pm 0.85$ & 0.2605 \\
Sap oranı, \% & 3 & $45.07 \pm 1.52^{\mathrm{A}}$ & $38.16 \pm 1.92^{\mathrm{B}}$ & $0.0475^{*}$ \\
Koçan/tabla oranı, \% & 3 & $37.13 \pm 0.71^{\mathrm{B}}$ & $45.60 \pm 1.32^{\mathrm{A}}$ & $0.0049^{* *}$ \\
Bitki boyu, m & 3 & $3.50 \pm 0.01^{\mathrm{A}}$ & $2.00 \pm 0.01^{\mathrm{B}}$ & $0.001^{* *}$ \\
\hline
\end{tabular}

${ }^{1}$ : Aynı satırda farklı harfleri taşıyan ortalamalar arasındaki farklılıklar önemlidir, ${ }^{*}: \mathrm{p}<0.05,{ }^{* *}: \mathrm{p}<0.01, \mathrm{n}$ : tekerrür sayısı, P: önemlilik düzeyi 
(Erdal ve ark., 2009). Doğu Karadeniz Bölgesi Giresun ili koşullarında mısır çeşitlerinin silajlık verimlerini inceleyen Han (2016), ortalama yeşil ot verimini $7776.3 \mathrm{~kg} \mathrm{da}^{-1}$, bitki boyunu $300.4 \mathrm{~cm}$ ve koçan oranını \% 30.8 olarak belirlemiştir. Ege Bölgesi İzmir ilinde farklı ön bitki ve ekim zamanı uygulamalarının silajlık mısırın verim ve bazı kalite özelliklerine etkilerini inceleyen Kavut ve Geren (2015) yeşil ot ve kuru madde verimi ile bitki boyunu sirasiyla $8217 \mathrm{~kg} \mathrm{da}^{-1}, 1959 \mathrm{~kg} \mathrm{da}^{-1} \mathrm{ve}$ $235.57 \mathrm{~cm}$ olarak bulmuşlardır. Orta Kızılırmak Havzası ekolojik koşullarında 20 farklı mısır çeşidinin silajlık olarak yetiştirilme olanaklarının belirlendiği bir çalışmada (Kuşvuran ve ark., 2015), OSSK 644 misır çeşidinin yeşil ot ve kuru madde verimi ile sap, yaprak ve koçan oranı ve bitki boyu değerleri sırasıyla; $9913 \mathrm{~kg} \mathrm{da}{ }^{-1}, 3093 \mathrm{~kg} \mathrm{da}$, $\% 46.1, \% 13.4$ ve $\% 40.5$ ve $260 \mathrm{~cm}$ olarak tespit edilmiştir.

Demirel ve ark. (2006) Van ekolojik koşullarında yaptıkları çalışmada, farklı olgunluk dönemlerinde biçilen ayçiçeği bitkisinde en yüksek yeşil ot verimi $\left(7261.43 \mathrm{~kg} \mathrm{da}{ }^{-1}\right)$ süt olum döneminde, en yüksek kuru madde verimi (1441.74 $\left.\mathrm{kg} \mathrm{da}^{-1}\right)$ ve tabla oranı (\% 38.73) hamur olum döneminde, en yüksek sap oranı $(\%$ 52.57) ve yaprak oranı (\% 30.70) çiçeklenme döneminde belirlemişlerdir. Erzurum koşullarında farklı ayçiçeği populasyonlarının silaj performansı üzerine hasat dönemi ve katkı maddelerinin etkisini inceleyen Dumlu Gül (2014) ortalama yeşil ot ve kuru madde verimi, sap, yaprak ve tablo oranı ile bitki boyunu sirasiyla $8283.5 \mathrm{~kg} \mathrm{da}^{-1}$ ve $1721.2 \mathrm{~kg}$ $\mathrm{da}^{-1}, \% 46.28, \% 20.04$ ve \% 33.71 ile $172.7 \mathrm{~cm}$ olduğunu ve bu değerlerin hasat dönemleri ve y1llara göre değişim gösterdiğini bildirmiştir. Van koşullarında farklı olgunluk dönemlerinde biçilen ayçiçeği bitkisinde en yüksek yeşil ot verimi $\left(8166.29 \mathrm{~kg} \mathrm{da}^{-1}\right)$ ve en yüksek kuru madde verimi (1980.32 $\mathrm{kg} \mathrm{da}^{-1}$ ) hamur olum döneminde, en yüksek sap oranı $(\%$ 57.63) ve yaprak oranı (\% 24.27) çiçeklenme döneminde tespit edilmiş, en yüksek tabla oranı $(\% 38.73)$ süt olum döneminde, en yüksek bitki boyları $(2.68 \mathrm{~m})$ ise süt ve hamur olum döneminde tespit edilmiş ve hasat döneminin geciktirilmesiyle kuru madde ve yeşil ot verimlerinin arttığı bildirilmiştir (Çelik, 2009). Erzurum koşullarında 4 farklı ayçiçeği genotipinde verim parametrelerini ve silaj kalitesini inceleyen Güney ve ark. (2012), yeşil ot ve kuru madde verimi, tabla oranı ve bitki boyunun sirasiyla; $4259.4-5140.0 \mathrm{~kg} \mathrm{da}{ }^{-1}, 1103.2-1345.7 \mathrm{~kg} \mathrm{da}{ }^{-1}$, \% 43.47-44.95 ve 152-183 cm arasında değiştiğini bildirmişlerdir. Yapılan başka bir çalışmada ise, farklı ekim zamanlarının silajlık ayçiçeğinin miktar ve silaj kalitesi üzerine etkileri araştırılmış ve en yüksek bitki boyu (1.72 m), sap oranı (\% 34.7), yaprak oranı (\% 17.4) Ekim ayında; en yüksek tabla oranı (\% 61.1), yeşil ot verimi $\left(2560 \mathrm{~kg} \mathrm{da}^{-1}\right)$, kuru madde verimi (766 $\mathrm{kg} \mathrm{da}^{-1}$ ) ile Aralık ayında ekildiğinde elde edildiği bildirilmektedir (Mello ve ark., 2006).

Silva ve ark. (1998), genotip, toprak verimliliği, sulama, ekim ve hasat zamanı ve birim alandaki bitki sayısı silajlık ayçiçeğinin verimini etkilediği, birim alandaki bitki yoğunluğu arttıkça ayçiçeğinin kuru madde veriminin arttığı ve ekim yoğunluğunun bitkilerin sap, yaprak ve tabla oranları ile kuru madde verimi arasında pozitif korelasyonların olduğunu bildirmektedirler.

Türkiye'de mısır ve ayçiçeği çeşitlerinin performanslar1, bölgelere göre ve ana ürün veya ikinci ürün yetiştirme durumlarına göre önemli ölçüde değişim göstermektedir. Burada en önemli sorunlardan biri doğru çeşidi doğru bölgede yetiştirmektedir. Türkiye'de 160 civarında tescilli veya üretim izinli mısır çeşidi bulunmaktadır. $\mathrm{Bu}$ çeşitlerin önemli bir bölümü tanelik yanında silajlık olarak da yetiştirilmektedir (Ergül, 2008). Çalışmamızda kullandığımız OSSK 644 misır çeşidi silajlık olarak tescilli olup FAO 500 olum grubunda orta geçci olarak nitelendirilmektedir. KAAN ayçiçeği çeşidi ise Tekirdağ Bölgesi'nde silajlık olarak yetiştirilmekte ancak silajlık çeşit olarak tescil edilmemiştir.

Araştırmamızda mısır ve ayçiçeği bitkilerinden elde edilen değerlerin, benzer ve/veya farklı ekolojik koşullarında yapılan araştırmalardan farklı değerler elde edilmesinin nedenleri; kullanılan çeşitlerin farklı verim potansiyeline sahip olması, araştırmaların yürütüldüğü yıllardaki iklim özelliklerinin farklı olması, araştırma topraklarının farklı fiziksel ve kimyasal özelliklere sahip olmasının yanı sıra; uygulanan yetiştirme tekniği işlemleri, ekim zamanı, bitki sıklığı ve hasat zamanı gibi kültürel işlemlerin farklılığından kaynaklanabileceği düşünülmektedir.

Mısır ve ayçiçeği silajlarının besin madde içeriklerine ilişkin en küçük kareler ortalaması ve standart hata sonuçları Tablo 2'de verilmiştir. Besin madde içerikleri incelendiğinde; $\mathrm{KM}, \mathrm{OM}, \mathrm{HK}, \mathrm{HP}$, HY ve ADF içeriği bakımından silajlar arasındaki farklılıklar çok önemli $(\mathrm{p}<0.001)$, NDF içeriği ise önemli $(p<0.05)$ bulunmuştur. Taze misır ve ayçiçeğinin KM oranı \% 27.60 ve \% 23.28 olarak belirlendiği araştırmada, fermantasyon süresince mısır ve ayçiçeği silajlarının KM oranları ise \% 26.66 ve \% 19.48 olarak belirlenmiş ve misır silajının KM oranı ayçiçeği silajından yüksek, ancak HK, HP, HY ve ADF oranları düşük bulunmuştur $(\mathrm{p}<0.0001)$. 
Tablo 2. Mısır ve ayçiçeği silajlarının besin madde içeriklerine ilişkin en küçük kareler ortalaması ve standart hata sonuçları $(\% \mathrm{KM})^{1}$

\begin{tabular}{lcrcc}
\hline Besin maddeleri (\%) & $\mathrm{n}$ & Misır silaj1 & Ayçiçeği silaj1 & P değeri \\
\hline KM & 7 & $26.66 \pm 0.79^{\mathrm{A}}$ & $19.48 \pm 0.56^{\mathrm{B}}$ & $0.0001^{* *}$ \\
OM & 7 & $94.85 \pm 0.09^{\mathrm{A}}$ & $88.97 \pm 0.11^{\mathrm{B}}$ & $0.0001^{* *}$ \\
HK & 7 & $5.15 \pm 0.09^{\mathrm{B}}$ & $11.02 \pm 0.11^{\mathrm{A}}$ & $0.0001^{* *}$ \\
HP & 7 & $4.80 \pm 0.03^{\mathrm{B}}$ & $11.19 \pm 0.05^{\mathrm{A}}$ & $0.0001^{* *}$ \\
HY & 7 & $6.69 \pm 0.21^{\mathrm{B}}$ & $14.63 \pm 0.40^{\mathrm{A}}$ & $0.0001^{* *}$ \\
ADF & 7 & $30.47 \pm 0.80^{\mathrm{B}}$ & $39.74 \pm 0.63^{\mathrm{A}}$ & $0.0001^{* *}$ \\
NDF & 7 & $50.89 \pm 0.83^{\mathrm{A}}$ & $47.42 \pm 0.85^{\mathrm{A}}$ & $0.0131^{*}$ \\
\hline
\end{tabular}

': Aynı satırda farklı harfleri taşıyan ortalamalar arasındaki farklılıklar önemlidir, ${ }^{*}: \mathrm{p}<0.05,{ }^{* *}: \mathrm{p}<0.01, \mathrm{n}$ : tekerrür sayısı, P: önemlilik düzeyi

Silo yemi kalitesinin belirlenmesi ve pratik değer taşıması bakımından silaj kaliteleri içerisinde en önemli kriter silajın içerdiği KM düzeyidir (Demirel ve ark., 2006). Ayçiçeğinde alt yaprakların sararması, tablanın tam dolması gibi kriterlere göre hasat anında belirlenen KM düzeyi \% 22.4 iken, misırda bu özellikler dikkate alınarak tespit edilen KM düzeyi \% 34.6 olarak saptanmıştır. Silo suyu ile kayı olmayacak ya da ihmal edilebilecek miktarda olabilecek șekilde silolama için önerilen minumum KM düzeyinin $\quad \% 22.9-$ \% 24.7 arasında değiştiği ve ayçiçeğinde en geç biçimde bile bu değerlerin minumum düzeyde kaldığı görülmüştür (Xing ve ark., 2009). Oliveira ve ark. (2010) tarafindan, farklı silaj türlerinin besin madde kompozisyonu üzerine yapılan karşılaştırmalı bir çalışmada, ayçiçeği bitki dokusunun yüksek düzeyde nem içeriğine sahip olduğu için ayçiçeği silajının daha düşük oranda (\% 22-25) kuru maddeye sahip olduğunu ve düşük kuru maddenin silo içerisinde Clostridium bakterlerinin gelişimine öncülük ederek silo içerisinde bütirik asit oranını arttırdığını bildirmişlerdir. Rodrigues ve ark. (2001) ayçiçeği silajlarında HP, HY, HK ve hücre duvarında lignin oranının mısır silajlarından daha yüksek olduğunu tespit etmişlerdir. Mello ve ark. (2004) HP, HY ve HK düzeylerini misır ve ayçiçeği silajları için sirasiyla \% 5.7, \% 4.2, \% 2.5 ve $\% 11.4, \% 17.4$, $\% 3.5$ olarak bulmuşlardır. Tan ve ark. (2015), 1800 $\mathrm{m}$ rakıma sahip bölgelerde silajlık ayçiçeğinin verimini ve silaj kalitesini mısır ile karşılaştırdıkları çalışmalarında; KM, HP, ADF ve NDF düzeylerini mısır ve ayçiçeği için sırasıyla \% 25.77, \% 9.53, $\% 26.64, \% 34.77$ ve \% 25.77, \% 12.75, \% 32.11, \% 36.27 olarak belirlemişler ve yüksek rakımlarda erken ilkbahar ve sonbaharda don risklerind en ayçiçeğinin etkilenmediğini ve gelişimini mısıra göre daha hızlı tamamladığını ve bu nedenle ayçiçeğinin bu bölgelerde alternatif bir silajlık bitki olduğunu ifade etmişlerdir.

Mısır ve ayçiçeği silajlarının fermantasyon özelliklerini inceleyen Martins ve ark. (2014); KM, HP, HY, ADF ve NDF içeriklerini mısır için sirasıyla $\% 28.7, \% 2.5, \% 24.2, \% 48.6$ ve ayçiçeği için sırasıyla \% 26.5, \% $10.5, \% \quad 15.7, \% 34.9$,
\% 39.9 olarak belirlemişlerdir. Yapılan çalışmaların çoğunda ayçiçeği silajının HP, HY, HK ve ADF içeriklerinin mısır silajından yüksek, KM ve NDF düzeylerinin ise düşük olduğu görülmüştür (Demirel ve ark., 2006; Mafakher ve ark., 2010a ve 2010b; Viana ve ark., 2012; Martins ve ark., 2014; Konca ve ark., 2015; Tan ve ark., 2015; Erdoğan ve Demirel, 2016; Konca ve ark., 2016).

\section{Sonuç ve Öneriler}

Dünyada mısır, silajlık materyal üretimi için ilk sırada yer almaktadır. Bu nedenle Van yöresinde silaj tekniğinin yaygınlaştırılabilmesi için mısır tarımındaki sorunların aşılması gerekir. Rakımı yüksek, yetiştirme periyodu kısa olan Doğu Anadolu Bölgesi için erkenci mısır çeşitlerinin belirlenmesi yanında, mısıra alternatif olan silajlık ayçiçeğinin de yaygınlaştırılması ile ilgili çalışmaların düzenli olarak devam etmesi gerekir. Bu bağlamda yapılan bu araştırma, Van ekolojik koşullarında silajlık ayçiçeği tarımının da yapılabileceğini ortaya koymaktadır.

\section{Kaynaklar}

Anonymous, 1990. Official Methods of Analysis of The Association of Analytical Chemists (AOAC). 15th Edition, Kenneth Arlington, Virginia 222201, USA.

Anonymous, 2017. SAS ${ }^{\circledR}$ User's Guide: Statistics, Version 8. SAS Institute Inc., Cary, NC.

Çelik, S., 2009. Farklı hasat dönemlerinde biçilen ayçiçeği hasılına artan düzeylerde enzim ilavesinin silaj kalitesi, rumen parametreleri ve ham besin maddelerinin sindirilebilirliği üzerine etkisi. Doktora tezi, Yüzüncü Yıl Üniversitesi Fen Bilimleri Enstitüsü, Van.

Demirel, M., Bolat, D., Çelik, S., Bakici, Y., Çelik, S., 2006. Quality of silages from sunflower harvested at different vegetational stages. Journal of Applied Animal Research, 30: 161-165.

Dumlu Gül, Z., 2014. Farklı ayçiçeği populasyonlarının silaj performansı üzerine hasat dönemi ve katk1 maddelerinin etkisi. Doktora tezi, Atatürk Üniversitesi Fen Bilimleri Enstitüsü, Erzurum.

Erdal, Ş., Pamukçu, M., Ekiz, H., Soysal, M., Savur, O., Toros, A., 2009. Bazı silajlık mısır çeşit adaylarının silajlık verim ve kalite özelliklerinin belirlenmesi. 
Akdeniz Üniversitesi Ziraat Fakültesi Dergisi, 22(1): 75-81.

Erdoğan, S., Demirel, M., 2016. Conservation characteristics and nutritive value of sunflower silages as affected by the maturity stages and fibrolytic enzymes. Turkish Journal of AgricultureFood Science and Technology, 4(6): 464-469.

Ergül, Y., 2008. Silajlık mısır çeşitlerinin önemli tarımsal ve kalite özelliklerinin belirlenmesi. Yüksek lisans tezi, Selçuk Üniversitesi Fen Bilimleri Enstitüsü, Konya.

Evengalista, A.R., Lima, J.A., 2001. Utilização de Silagem de Girassol na Alimentação Animal. Simpósio Sobre Produção e Utilização de Forragens Conservadas, p. 177-217.

Güney, E., Tan, M., Gül, Z.D., Gül, İ., 2010. Erzurum şartlarında bazı silajlık mısır çeşitlerinin verim ve silaj kalitelerinin belirlenmesi. Atatürk Üniversitesi Ziraat Fakültesi Dergisi, 41(2): 105-111.

Güney, E., Tan, M., Yolcu, H., 2012. Yield and quality characteristics of sunflower silages in highlands. Turkish Journal of Field Crops, 17(1): 31-34.

Han, E., 2016. Bazı mısır çeşitlerinin dane verimleri ile silaj ve kalite özelliklerinin belirlenmesi. Yüksek lisans tezi, Ordu Üniversitesi Fen Bilimleri Enstitüsü, Ordu.

İptaş, S., Yılmaz, M., Aktaş, A., 1997. Tokat ekolojik koşullarında sorgum-sudanotu melezinde ekim normu ve azotlu gübre uygulamalarının verim ve kaliteye etkisi. Türkiye 2. Tarla Bitkileri Kongresi, 22-25 Eylül, Samsun, s. 477-481.

Kavut, Y.T., Geren, H., 2015. Farklı ön bitki ve ekim zamanı uygulamalarının silajlık misırın (Zea mays L.) verim ve bazı kalite özelliklerine etkileri. Türk Tarım ve Doğa Bilimleri Dergisi, 2(2): 163-170.

Kırtok, Y., 1998. Mısır, Üretimi ve Kullanımı. Kocaoluk Basım ve Yayınevi, İstanbul.

Konca, Y., Beyzi, S.B., Kalıber, M., Ülger, İ., 2015. Chemical and nutritional changes in sunflower silage associated with molasses, lactic acid bacteria and enzyme supplementation. Harran Tartm ve Gida Bilimleri Dergisi, 19(4): 223-231.

Konca, Y., Beyzi, S.B., Ayaşan, T., Kaliber, M., Kiraz, A.B., 2016. The effects of freezing and supplementation of molasses and inoculants on chemical and nutritional composition of sunflower silage. Asian Australasian Journal of Animal Science, 29(7): 965-970.

Kuşvuran, A., Kaplan, M., Nazlı, R.İ., Saruhan, V., Karadağ, Y., 2015. Orta Kızılırmak havzası ekolojik koşullarında bazı mısır (Zea mays L.) çeşitlerinin silajlık olarak yetiştirilme olanaklarının belirlenmesi. Gaziosmanpasa Üniversitesi Ziraat Fakültesi Dergisi, 32(1): 57-67.

Mafakher, E., Meskarbashee, M., Hassibi, P., Mashayekhi, M.R., 2010a. Study of chemical composition and quality characteristics of corn, sunflower and corn-sunflower mixture silages. Asian Journal of Animal Veterinary Advances, 5: 175-179.

Mafakher, E., Meskarbashee, M., Hassibi, P., Mashayekhi, M.R., 2010b. Evaluation of sunflower silage in different developmental stages. Asian
Journal of Crop Science, 2(1): 20-24.

Martins, A.D.S., Oliveira, J.R., Lederer, M.L., Moletta, J.L., Galetto, S.L., Pedrosa, V.B., 2014. Níveis de inclusão de glicerol nas silagens de milho e girassol. Ciênca Agrotecnologia, 38(5): 497-505.

Mello, R., Nörnberg, J.L., Rocha, M.G., 2004. Potencial produtivo e qualitativo de híbridos de milho, sorgo e girassol para ensilagem. Revista Brasileira de Agrociência, 10(1): 87-95.

Mello, R., Nörnberg, J.L., Restle, J., Neumann, M., César de Queiroz, A., Costa, P.B., Magalhães, A.L.R., Bitencourt de David, D., 2006. Características fenológicas, produtivas e qualitativas de híbridos de girassol em diferentes épocas de semeadura para produção de silagem. Revista Brasileira de Zootecnia, 35(3): 672-682.

Oliveira, L.B.D., Pires, A.J.V., Carvalho, G.G.P.D., Ribeiro, L.S.O., Almeida, V.V.D., Peixoto, C.A.D.M., 2010. Perdas e valor nutritivo de silagens de milho, sorgo-sudão, sorgo forrageiro e girassol. Revista Brasileira de Zootecnia, 39(1): 61-67.

Rodrigues, P.H.M., Almeida, M.T., Melotti, L., Andrade, S.J.T., Júnior, K.C.P., 2001. Efeitos da adição de inoculantes microbianos sobre a composição bromatológica e sobre a fermentação da silagem de girassol produzida em silos experimentais. Revista Brasileiran de Zootecnia, 30(6): 2169-2175.

Serin, Y., Tan, M., 1998. Doğu Anadolu Bölgesi'nde kaba yem üretimi, ihtiyacı ve yem bitkileri tarımının geliştirilmesi. Doğu Anadolu Tarım Kongresi, 14-18 Eylül, Erzurum, s. 407-418.

Silva, A.W.L., Macedo, A.F., Hoeschl Neto, W., 1998. Efeito da densidade de semeadura sobre a produtividade e composição bromatológica de silagens de girassol. XXXV. Reunião Anual Da Sociedade Brasiletra De Zootecnia, 11-13 July, Botucatu, p. 635-637.

Tan, M., Yolcu, H., Gül, Z.D., 2015. Nutritive value of sunflower silages ensiled with corn or alfalfa at different rate. Journal of Agricultural Sciences, 21: 184-191.

Van Soest, P.J., Robertson, J.B., 1979. Systems of analyses for evaluation of fibrous feed. In: W. J. Pigden, C. C. Balch, M. Graham (Eds.), Workshop on Standardization of Analytical Methodology for Feeds, Ottowa, pp. 49-60.

Viana, P.T., Pires, A.J.V., Oliveira, L.B., Carvalho, G.G.P., Ribeiro, L.S.O., Chagas, D.M.T., Filho, C.S.N., Carvalho, A.O., 2012. Fracionamento de carboidratos e de proteína das silagens de diferentes forrageiras. Revista Brasileira de Zootecnia, 41(2): 292-297.

Xing, L., Chen, L., Han, L., 2009. The effect of an inoculant and enzymes on fermentation and nutritive value of sorghum straw silages. Bioresource Technology, 100: 488-491.

Yılmaz, İ., Hoşaflıoğlu, İ., 1999. Van'ın Gürpınar ilçesinde yetiştirilen bazı silajlık mısır çeşitlerinin verim ve tarımsal karakterlerinin saptanması. Uluslararası Hayvancılık'99 Kongresi, 21-24 Eylül, İzmir, s. 237-241. 